\title{
Rumen fermentation and performance of Hanwoo steers fed total mixed ration with Korean rice wine residue
}

\author{
Chang-Dae Jeong ${ }^{1}$, Lovelia L. Mamuad ${ }^{1}$, Jong Youl Koํ․ Ha Guyn Sung ${ }^{3}$, Keun Kyu Park ${ }^{4}$, Yoo Kyung Lee ${ }^{5}$ \\ and Sang-Suk Lee ${ }^{1 *}$
}

\begin{abstract}
Background: This study was conducted to evaluate the effects of adding Korean rice wine residue (RWR) in total mixed ration (TMR) on in vitro ruminal fermentation and growth performance of growing Hanwoo steers.

Methods: For in vitro fermentation, the experimental treatments were Control (Con: $0 \%$ RWR + TMR), Treatment 1 (T1: $10 \%$ RWR + TMR), and Treatment 2 (T2: $15 \%$ RWR + TMR). The rumen fluid was collected from three Hanwoo steers and mixed with buffer solution, after which buffered rumen fluid was transferred into serum bottles containing $2 \mathrm{~g}$ dry matter (DM) of TMR added with or without RWR. The samples were then incubated for $0 \mathrm{~h}, 12 \mathrm{~h}, 24 \mathrm{~h}$, or $48 \mathrm{~h}$ at $39^{\circ} \mathrm{C}$ and $100 \mathrm{rpm}$. For the in vivo experiment, 27 Hanwoo steers (6 months old) with an average weight of $196 \pm$ $8.66 \mathrm{~kg}$ were subjected to a 24-week feeding trial. The animals were randomly selected and equally distributed into three groups. After which the body weight, feed intake and blood characteristics of each group were investigated.

Results: The $\mathrm{pH}$ of the treatments decreased significantly relative to the control during the $12 \mathrm{~h}$ of incubation. Total gas production and ammonia nitrogen $\left(\mathrm{NH}_{3}-\mathrm{N}\right)$ was not affected by RWR addition. The total volatile fatty acid (VFA) was lower after $24 \mathrm{~h}$ of incubation but at other incubation times, the concentration was not affected by treatments. Feed cost was $8 \%$ and $15 \%$ lower in T1 and T2 compared to control. Blood alcohol was not detected and a significant increase in total weight gain and average daily gain were observed in Hanwoo steers fed with RWR.
\end{abstract}

Conclusion: Overall, the results of this study suggest that TMR amended with $15 \%$ RWR can be used as an alternative feed resource for ruminants to reduce feed cost.

Keywords: By-products, Hanwoo steers, In vitro, Korean rice wine residue

\section{Background}

Over the last decade, cattle feed costs have increased by up to $70-80 \%$. This has caused a burden to Korean farmers (Korea Feed Association, 2014). Accordingly, there is now a demand for low cost alternative feedstuffs. One possible alternative is the by-products. By products are derived from food processing and manufacturing that cannot be used as food for humans, but often contains high nutrients and are fairly inexpensive. Food manufacturing by-products are distiller's dried grains

\footnotetext{
* Correspondence: rumen@sunchon.ac.kr

${ }^{1}$ Ruminant Nutrition and Anaerobe Laboratory, Department of Animal Science and Technology, College of Bio-industry Science, Sunchon National University, 413 Jungang-ro, Suncheon, Jeonnam 57922, Republic of Korea Full list of author information is available at the end of the article
}

with solubles, tofu cake, rice bran, and wet green tea waste. They are high in crude protein $(\mathrm{CP})$, fatty acids, tannins, and vitamins [1] and therefore have been great potential for utilization as animal feed. For example, corn distillers dried grain with soluble diets have replaced up to $40 \%$ of total feed as a protein source in the United States [2] and the use of wet distillers grain (WDG) up to $10 \%$ in total mixed ration (TMR) did not show any negative effect on the performance of Hanwoo steers [3].

In search for alternative feed, we found out that there are 681 Korean traditional rice wine (Makgeolli) processing companies in South Korea. These companies annually produce about 83,808 tons of Korean rice wine residues (RWR). Korean rice wine residues contain high 
protein and energy source [4]. However, RWR has high moisture content of about $60-70 \%$. Also, it is currently not used by agricultural sector due to insufficient data regarding its characteristics and effects. And as a result, rice wine manufacturing companies usually dispose RWR by burning or landfill, which causes environmental problems. In view of these economic and environmental concerns, strategies to efficiently utilize industrial byproducts are necessary. Thus, the objective of this study was to evaluate the effects of wet TMR including rice wine residue as replacement for concentrate on in vitro ruminal fermentation and growth performance of growing Hanwoo steers.

\section{Methods}

\section{Experimental feed and treatments}

Korean rice wine residue has an average DM, CP, EE, CF, ash, and NFE contents of $49 \%, 9.18 \%, 0.66 \%, 0.88$ $\%, 0.35 \%$, and $37.07 \%$, respectively. Korean rice wine residue was drained and stabilized for $48 \mathrm{~h}$ prior to incorporation into the animal feeds. Total mixed ration feed was formulated based on the standard tables of feed composition provided by the Korean National Institute of Animal Science (2007). The composition, nutrient content and feed cost of the feed used in each treatment in the present study are provided in Table 1 . The chemical compositions were analyzed according to the guidelines of the Association of Official Analytical Chemists [5], while neutral detergent fiber (NDF) and acid detergent fiber (ADF) were measured using an Ankom fiber analyzer (Ankom Tech. Corp, Fairport, NY, USA) based on the method described by Van Soest et al. (1991). The experimental feeds consisted of a control (non-addition of RWR), Treatment 1 (feed containing RWR at $10 \%$ ), or Treatment 2 (feed containing RWR at $15 \%$ ) on a percent $\mathrm{DM}$ basis.

\section{Experiment 1: In vitro rumen fermentation}

Rumen fluid collected from the rumens of three slaughtered 30-month old Hanwoo steers $(700 \mathrm{~kg}$ body weight), strained through four layers of surgical gauze, and then pooled in amber bottles with oxygen-free headspace. The bottles were subsequently sealed and immediately transported to the laboratory while maintaining the temperature at $39{ }^{\circ} \mathrm{C}$. Russell and Van Soest [6] buffer solution ( $\mathrm{pH} 7)$ was mixed with rumen fluid at a 3:1 ratio, after which $100 \mathrm{ml}$ of the mixture was anaerobically dispensed into $160-\mathrm{ml}$ serum bottles under $\mathrm{O}_{2}$-free $\mathrm{CO}_{2}$. The bottles were then sealed with rubber stoppers and aluminum caps and incubated with shaking (100 rpm) at $39^{\circ} \mathrm{C}$ for $0 \mathrm{~h}, 12 \mathrm{~h}, 24 \mathrm{~h}$ or $48 \mathrm{~h}$. Total gas (TG), $\mathrm{pH}, \mathrm{NH}_{3}-\mathrm{N}, \mathrm{VFA}$ and other metabolites were analyzed after incubation.
Table 1 Composition, nutrient content and feed cost of total mixed ration containing Korean rice wine residue (RWR) at different inclusion rates for Hanwoo steers at growing stage

\begin{tabular}{|c|c|c|c|}
\hline \multirow[t]{2}{*}{ Parameters } & \multicolumn{3}{|c|}{ Treatments } \\
\hline & Con & $\mathrm{T} 1$ & $\mathrm{~T} 2$ \\
\hline \multicolumn{4}{|l|}{ Feed composition(\% of DM) } \\
\hline Oat hay & 41.32 & 38.17 & 36.26 \\
\hline Timothy hay & 14.75 & 13.63 & 13.79 \\
\hline Alfalfa hay & 4.77 & 4.41 & 4.46 \\
\hline Wheat grain & 4.78 & 3.19 & 3.23 \\
\hline Corn & 18.34 & 15.72 & 15.91 \\
\hline Corn gluten feed & 3.34 & 3.12 & 3.16 \\
\hline Lupine & 6.63 & 6.13 & 6.20 \\
\hline Brewers grain & 4.13 & 3.82 & 0.00 \\
\hline Salt & 0.28 & 0.26 & 0.26 \\
\hline Limestone & 0.58 & 0.53 & 0.54 \\
\hline $\mathrm{RWR}^{\mathrm{a}}$ & 0.00 & 10.03 & 15.19 \\
\hline Molasses & 0.55 & 0.50 & 0.50 \\
\hline Vitamin-mineral mix & 0.53 & 0.49 & 0.50 \\
\hline \multicolumn{4}{|l|}{ Nutrient content (\% of DM) } \\
\hline Crude protein (CP) & 14.62 & 15.52 & 15.56 \\
\hline Ether extract (EE) & 3.93 & 3.60 & 3.22 \\
\hline Ash & 9.60 & 10.10 & 9.65 \\
\hline Crude fiber (CF) & 18.58 & 24.17 & 24.39 \\
\hline Nitrogen free extract (NFE) & 53.27 & 46.61 & 47.17 \\
\hline Neutral detergent fiber (NDF) & 49.13 & 61.67 & 59.91 \\
\hline Acid detergent fiber (ADF) & 34.94 & 36.03 & 34.78 \\
\hline Total digestible nutrient (TDN) ${ }^{\mathrm{b}}$ & 66.12 & 65.40 & 66.22 \\
\hline
\end{tabular}

${ }^{\mathrm{a}}$ Korean rice wine residue; ${ }^{\mathrm{b}} \mathrm{TDN}=88.936-\left(0.653^{*} \mathrm{ADF}\right)$

Control (Con: $0 \%$ RWR + TMR), Treatment 1 (T1: $10 \%$ RWR + TMR), Treatment 2 (T2: $15 \%$ RWR + TMR)

\section{Experiment 2: Growth performance and blood profiles}

A 150-day feeding trial was conducted using 27 Hanwoo steers (6 months old) with body weights of $196 \mathrm{~kg} \pm$ $8.66 \mathrm{~kg}$. The animals were divided into three treatment groups (nine animals per group) and fed one of the three experimental diets, namely: Control (Con: $0 \%$ RWR + TMR), Treatment 1 (T1: $10 \%$ RWR + TMR), and Treatment 2 (T2: $15 \%$ RWR + TMR). Three cattle were confined in experimental pens $(5 \mathrm{~m} \times 10 \mathrm{~m})$ constructed of steel. The cattle house faced south to ensure proper light exposure.

Experimental TMR diets were provided to the animals daily at $2 \%$ of body weight. The total amount of daily feed required was divided into morning (8:00) and afternoon (17:00) feeding. All animals were given free access to fresh drinking water and trace mineral salts (NongHyup, Inc.) throughout the experiment. The experimental cattle were permitted to adapt to the diets for two wk prior to the actual feeding trial. Initial weights of 
the animals were measured after the acclimatization period, while final body weights were determined and blood samples were collected at the end of the feeding trial.

\section{Analyses and data collection}

Experiment 1- Fermentation parameters were monitored at the end of each incubation time set. $\mathrm{pH}$ was measured with a Pinnacle series M530p meter (Schott Instruments, Mainz, Germany) after uncapping each bottle. To measure the total gas, a press and sensor machine was used (Laurel Electronics, Inc., Costa Mesa, CA). Briefly, a needle channel connected to the machine was extended into the sealed fermentation bottle to measure the positive pressure created by the gas build up in the headspace of the bottle at room temperature. A gas flow regulator was subsequently opened, allowing the gas to flow inside a syringe barrel. The plunger was pulled gradually until the pressure reading in the machine display red zero and the volume of gas trapped inside the barrel was recorded as the total gas produced in $\mathrm{ml}$.

Additionally, $1 \mathrm{ml}$ fermenta from each of the serum bottles was immediately centrifuged at $16,609 \times g$ for $10 \mathrm{~min}$ at $4{ }^{\circ} \mathrm{C}$ using a Micro $17 \mathrm{TR}$ centrifuge (Hanil Science Industrial Co. Ltd., Korea). The supernatant was kept in $1.5 \mathrm{ml}$ Eppendorf tubes and deep frozen at $-80^{\circ}$ $\mathrm{C}$ until ammonia-N and VFA analysis. The ammonia-N concentration was measured according to the methods developed by Chaney and Marbach [7] using a Libra S22 spectrophotometer (Biochrom Ltd., CB40FJ, England) at an absorbance of $630 \mathrm{~nm}$. For determination of VFA concentrations, samples contained in Eppendorf tubes were thawed at room temperature, after which they were filtered through $0.2 \mu \mathrm{m}$ Millipore filters. Standards were made $R^{2}$ at 0.999 prior to sample analysis. Volatile fatty acid concentrations were measured using high performance liquid chromatography (Agilent Technologies 1200 series, Germany) with a UV detector set at $210 \mathrm{~nm}$ and $220 \mathrm{~nm}$. MetaCarb 87H (Varian, Germany) column with $0.0085 \mathrm{~N} \mathrm{H}_{2} \mathrm{SO}_{4}$ buffer applied at a rate of $0.6 \mathrm{ml} / \mathrm{min}$ was used in the determination of fermentation products [8]. The VFA concentration in $\mathrm{mM}$ was calculated as parts per million divided by their molecular weight.

Experiment 2- Feed intake and weight gain determination: Voluntary feed intake was calculated as the difference between feed supplied and refusals. Weight gains by the animal $(\mathrm{kg})$ were calculated as the difference between the initial body weights taken before the start of the feeding trial and the final body weights taken at the end of the experiment. Average daily gain (ADG) was calculated as weight gained in kilograms divided by the experimental period (150 d). Feed efficiency (FE) was calculated as the ratio of weight gain to the amount of feed consumed. At the end of the experiment period, five $\mathrm{ml}$ blood samples were collected from the jugular vein of the animals into sterilized vacuum tubes (Green Cross MS, Korea) containing K3-EDTA. The tubes were gently inverted several times, kept in an ice box, and then centrifuged for $15 \mathrm{~min}$ at $890 \times \mathrm{g}$ at $4{ }^{\circ} \mathrm{C}$, after which they were stored for eight $h$ in a refrigerator at $4{ }^{\circ} \mathrm{C}$ prior to separation and analysis of the serum. The plasma was also transferred to a storage tube and labeled with the date and animal identification, then analyzed fresh or stored at $-20^{\circ}$ $\mathrm{C}$ until analysis. Total alcohol, protein, albumin, creatinine, blood urea nitrogen and glucose concentrations were analyzed using an automatic blood analyzer (Express Plus, Ciba-Corning, CA, USA). Serum glutamic oxaloacetic transaminase (SGOT), serum glutamic pyruvic transaminase (SGPT), total cholesterol, high density lipoprotein (HDL), low density lipoprotein (LDL) and triglyceride concentrations in the blood samples were analyzed by Green Cross Corp., Gyeonggido, Korea.

\section{Statistical analysis}

Data were analyzed by analysis of variance (ANOVA) using the general linear model (GLM) for a randomized complete block design. All treatments were conducted in triplicates. Duncan's Multiple Range Test and Orthogonal Polynomial Contrast were used to identify differences between and among treatments and control. A $P<0.05$ was considered to indicate statistical significance. All analyses were carried out using Statistical Analysis Systems (SAS) version $9.1[9]$.

\section{Results}

\section{Rumen fermentation characteristics}

Inclusion of RWR resulted in non-significant total gas production between control and treatment groups, with $120.67 \mathrm{ml}$ to $122.00 \mathrm{ml}$ and $150.33 \mathrm{ml}$ to $166.33 \mathrm{ml}$ of gas being produced at $24 \mathrm{~h}$ and $48 \mathrm{~h}$, respectively. Similarly, $\mathrm{pH}$ was higher $(P<0.05)$ in control than the treatment groups after $12 \mathrm{~h}$ of incubation, but nonsignificant values ranging from 6.23 to 6.30 at $24 \mathrm{~h}$, and 6.16 to 6.18 at $48 \mathrm{~h}$ were observed. Ammonia nitrogen $\left(\mathrm{NH}_{3}-\mathrm{N}\right)$ concentrations were significantly higher in control and T1 than T2 after $12 \mathrm{~h}$ of incubation and the concentrations became comparable after $24 \mathrm{~h}$ and $48 \mathrm{~h}$ of incubation (Table 2).

At $12 \mathrm{~h}$ and $24 \mathrm{~h}$, the acetate concentrations were higher $(P<0.05)$ in the control $(31.74 \mathrm{mM}$ and $38.05 \mathrm{mM})$ and $\mathrm{T} 1(28.52 \mathrm{mM}$ and $36.04 \mathrm{mM})$ than $\mathrm{T} 2(26.64 \mathrm{mM}$ and $32.54 \mathrm{mM})$. Additionally, propionate concentration was higher $(P<0.05)$ in the control (18.44 $\mathrm{mM})$ and $\mathrm{T} 1(16.49 \mathrm{mM})$ than $\mathrm{T} 2(12.60 \mathrm{mM})$ while butyrate concentration was highest $(P<0.05)$ in T2 by $6.81 \mathrm{mM}$ and $4.82 \mathrm{mM}$ relative to the control and $\mathrm{T} 1$, respectively after $24 \mathrm{~h}$ of incubation (Table 3 ). Total VFA 
Table 2 In vitro rumen fermentation parameters as affected by the addition of Korean rice wine residue (RWR)

\begin{tabular}{|c|c|c|c|c|c|c|c|}
\hline \multirow[t]{2}{*}{ Parameters } & \multirow{2}{*}{$\begin{array}{l}\text { Incubation } \\
\text { time (h) }\end{array}$} & \multirow[t]{2}{*}{ Con } & \multirow[t]{2}{*}{$\mathrm{T} 1$} & \multirow[t]{2}{*}{$\mathrm{T} 2$} & \multirow[t]{2}{*}{ SEM } & \multicolumn{2}{|c|}{$P$ value } \\
\hline & & & & & & All & C vs T \\
\hline \multirow[t]{4}{*}{ Total gas (ml) } & 0 & 62.67 & 65.00 & 64.33 & 1.181 & 0.460 & 0.248 \\
\hline & 12 & 104.00 & 100.67 & 101.33 & 1.264 & 0.312 & 0.149 \\
\hline & 24 & 122.00 & 120.67 & 121.00 & 1.953 & 0.884 & 0.643 \\
\hline & 48 & 150.33 & 155.00 & 166.33 & 10.630 & 0.608 & 0.479 \\
\hline \multirow[t]{4}{*}{$\mathrm{pH}$} & 0 & 6.60 & 6.62 & 6.64 & 0.014 & 0.163 & 0.101 \\
\hline & 12 & $6.43^{\mathrm{a}}$ & $6.38^{\mathrm{ab}}$ & $6.28^{c}$ & 0.033 & 0.046 & 0.049 \\
\hline & 24 & 6.23 & 6.27 & 6.30 & 0.050 & 0.655 & 0.411 \\
\hline & 48 & 6.18 & 6.18 & 6.16 & 0.044 & 0.949 & 0.876 \\
\hline \multirow[t]{4}{*}{ Ammonia Nitrogen (mM) } & 0 & 3.39 & 3.41 & 3.44 & 0.490 & 0.998 & 0.956 \\
\hline & 12 & $5.77^{\mathrm{a}}$ & $5.26^{\mathrm{a}}$ & $3.65^{\mathrm{b}}$ & 0.281 & 0.029 & 0.031 \\
\hline & 24 & 7.65 & 6.09 & 6.19 & 0.887 & 0.598 & 0.340 \\
\hline & 48 & 13.54 & 11.25 & 12.56 & 1.362 & 0.586 & 0.408 \\
\hline
\end{tabular}

Values are shown as mean. Means for the same period $(0 \mathrm{~h}, 12 \mathrm{~h}, 24 \mathrm{~h}$, or $48 \mathrm{~h}$ ) marked with the same letters (a $>\mathrm{b}>\mathrm{c})$ did not differ significantly within treatments $(P<0.05)$, as determined by Duncan's multiple range test. SEM is the standard error mean. $C$ vs $T$ is the comparison between control and treatments. Control (Con: $0 \%$ RWR + TMR), Treatment 1 (T1: $10 \%$ RWR + TMR), Treatment 2 (T2: $15 \%$ RWR + TMR)

concentration was highest $(P<0.05)$ in the control, the $24 \mathrm{~h}$ incubation time, the VFA concentration did not followed by $\mathrm{T} 1$ and $\mathrm{T} 2$ with concentrations of $69.95 \mathrm{mM}$, differ significantly among groups. $63.35 \mathrm{mM}$, and $60.78 \mathrm{mM}$, respectively at $24 \mathrm{~h}$. Except for

Table 3 In vitro volatile fatty acid concentration as affected by the addition of Korean rice wine residue (RWR)

\begin{tabular}{|c|c|c|c|c|c|c|c|}
\hline \multirow[t]{2}{*}{ Parameters } & \multirow{2}{*}{$\begin{array}{l}\text { Incubation } \\
\text { time (h) }\end{array}$} & \multirow[t]{2}{*}{ Con } & \multirow[t]{2}{*}{$\mathrm{T} 1$} & \multirow[t]{2}{*}{$\mathrm{T} 2$} & \multirow[t]{2}{*}{ SEM } & \multirow{2}{*}{$\begin{array}{l}P \text { value } \\
\text { All }\end{array}$} & \multirow{2}{*}{$\begin{array}{l}P \text { value } \\
C \text { vs T }\end{array}$} \\
\hline & & & & & & & \\
\hline Acetate & 0 & 23.88 & 23.56 & 23.57 & 0.163 & 0.075 & 0.081 \\
\hline \multirow[t]{3}{*}{$(\mathrm{mM})$} & 12 & $31.74^{\mathrm{a}}$ & $28.52^{\mathrm{ab}}$ & $26.64^{b}$ & 1.348 & 0.101 & 0.050 \\
\hline & 24 & $38.05^{\mathrm{a}}$ & $36.04^{\mathrm{ab}}$ & $32.54^{b}$ & 1.310 & 0.075 & 0.067 \\
\hline & 48 & 41.81 & 41.21 & 40.77 & 0.361 & 0.387 & 0.224 \\
\hline Propionate & 0 & 5.09 & 5.10 & 5.24 & 0.059 & 0.238 & 0.199 \\
\hline \multirow[t]{3}{*}{$(\mathrm{mM})$} & 12 & 13.87 & 11.06 & 9.79 & 1.238 & 0.169 & 0.080 \\
\hline & 24 & $18.44^{\mathrm{a}}$ & $16.49^{a}$ & $12.60^{b}$ & 0.558 & 0.017 & 0.016 \\
\hline & 48 & 20.64 & 19.14 & 19.92 & 0.574 & 0.297 & 0.191 \\
\hline Butyrate & 0 & ND & ND & ND & ND & ND & ND \\
\hline \multirow[t]{3}{*}{ (mM) } & 12 & $8.51^{\mathrm{a}}$ & $7.38^{\mathrm{ab}}$ & $5.71^{b}$ & 0.568 & 0.062 & 0.051 \\
\hline & 24 & $8.83^{b}$ & $10.82^{b}$ & $15.64^{\mathrm{a}}$ & 1.060 & 0.015 & 0.021 \\
\hline & 48 & 11.74 & 12.12 & 15.28 & 1.735 & 0.404 & 0.430 \\
\hline Total VFA & 0 & 28.97 & 28.67 & 28.81 & 0.087 & 0.269 & 0.236 \\
\hline \multirow[t]{3}{*}{$(\mathrm{mM})$} & 12 & 54.13 & 46.96 & 42.15 & 2.699 & 0.068 & 0.017 \\
\hline & 24 & $69.95^{a}$ & $63.35^{b}$ & $60.78^{b}$ & 1.569 & 0.014 & 0.030 \\
\hline & 48 & 74.19 & 72.47 & 75.98 & 2.379 & 0.578 & 0.761 \\
\hline \multirow[t]{4}{*}{$A: P$} & 0 & $4.69^{a}$ & $4.62^{\mathrm{ab}}$ & $4.50^{b}$ & 0.025 & 0.001 & 0.002 \\
\hline & 12 & 2.33 & 2.64 & 2.73 & 0.155 & 0.243 & 0.302 \\
\hline & 24 & 2.32 & 2.21 & 2.59 & 0.105 & 0.126 & 0.057 \\
\hline & 48 & 2.03 & 2.15 & 2.05 & 0.052 & 0.409 & 0.330 \\
\hline
\end{tabular}

Values are shown as mean. Means for the same period $(0 \mathrm{~h}, 12 \mathrm{~h}, 24 \mathrm{~h}$, or $48 \mathrm{~h}$ ) marked with the same letters (a $>\mathrm{b}>\mathrm{c}$ ) did not differ significantly within treatments $(P<0.05)$, as determined by Duncan's multiple range test. SEM is the standard error mean. $C$ vs $T$ is the comparison between control and treatments. Control (Con: $0 \%$ RWR + TMR), Treatment 1 (T1: $10 \%$ RWR + TMR), Treatment 2 (T2: $15 \%$ RWR + TMR) 
Table 4 Growth performance and blood profiles of Hanwoo steers fed with or without Korean rice wine residue

\begin{tabular}{|c|c|c|c|c|c|c|}
\hline \multirow[t]{2}{*}{ Parameters } & \multirow[t]{2}{*}{ Con } & \multirow[t]{2}{*}{$\mathrm{T} 1$} & \multirow[t]{2}{*}{$\mathrm{T} 2$} & \multirow[t]{2}{*}{ SEM } & \multicolumn{2}{|c|}{$P$ value } \\
\hline & & & & & All & C vs T \\
\hline \multicolumn{7}{|l|}{ Growth performance } \\
\hline Total gain $(\mathrm{kg})$ & $153.33^{b}$ & $168.00^{\mathrm{a}}$ & $160.83^{\mathrm{ab}}$ & 2.816 & 0.013 & 0.009 \\
\hline $\mathrm{ADG}(\mathrm{kg} / \mathrm{d})$ & $1.00^{\mathrm{b}}$ & $1.09^{\mathrm{a}}$ & $1.04^{\mathrm{ab}}$ & 0.018 & 0.012 & 0.008 \\
\hline Feed intake & 9.81 & 9.70 & 9.90 & 0.105 & 0.04 & 0.845 \\
\hline Feed efficiency & 0.102 & 0.112 & 0.105 & 0.002 & 0.053 & 0.082 \\
\hline \multicolumn{7}{|l|}{ Blood profiles } \\
\hline Ethanol (\%) & 0 & 0 & 0 & 0 & - & \\
\hline Albumin (g/dL) & 3.68 & 3.66 & 3.87 & 0.088 & 0.202 & 0.45 \\
\hline AST/SGOT (U/L) & 66.78 & 59 & 59.89 & 3.406 & 0.246 & 0.099 \\
\hline ALT/SGPT (U/L) & 26.89 & 23.89 & 24.00 & 1.673 & 0.374 & 0.165 \\
\hline Glucose (mg/dL) & 63.00 & 60.56 & 69.56 & 3.044 & 0.124 & 0.591 \\
\hline T. Chol (mg/dL) & 114.22 & 110 & 123.33 & 6.248 & 0.358 & 0.764 \\
\hline Triglyceride (mg/dL) & 26.11 & 25.44 & 30.44 & 2.571 & 0.356 & 0.572 \\
\hline $\mathrm{LDL}(\mathrm{mg} / \mathrm{dL})$ & 17.33 & 14.89 & 18.44 & 1.202 & 0.124 & 0.655 \\
\hline $\mathrm{HDL}(\mathrm{mg} / \mathrm{dL})$ & $99.33^{b}$ & $96.56^{b}$ & $108.44^{a}$ & 5.804 & 0.369 & 0.675 \\
\hline Creatinine (mg/dL) & $0.80^{b}$ & $0.80^{b}$ & $0.97^{\mathrm{a}}$ & 0.047 & 0.028 & 0.178 \\
\hline $\mathrm{BUN}(\mathrm{mg} / \mathrm{dL})$ & $14.14^{b}$ & $16.47^{\mathrm{a}}$ & $11.04^{c}$ & 0.755 & 0 & 0.679 \\
\hline Total protein (g/dL) & $6.39^{\mathrm{ab}}$ & $6.19^{b}$ & $6.61^{\mathrm{a}}$ & 0.107 & 0.04 & 0.935 \\
\hline
\end{tabular}

Values are shown as mean. Means for the same period ( 0 h, 12 h, 24 h, or 48 h) marked with the same letters (a > b > c) did not differ significantly within treatments $(P<0.05)$, as determined by Duncan's multiple range test. SEM is the standard error mean. $C$ vs $\mathrm{T}$ is the comparison between control and treatments. Control (Con: $0 \%$ RWR + TMR), Treatment 1 (T1: $10 \%$ RWR + TMR), Treatment 2 (T2: $15 \%$ RWR + TMR)

\section{Growth performance and blood profiles}

The feed cost was $8 \%$ and $15 \%$ lower in $\mathrm{T} 1$ and $\mathrm{T} 2$ compared to control. Table 4 shows the growth performance and blood profiles of Hanwoo steers fed with TMR mixed with or without RWR. T1 had the highest total weight gain $(P=0.013)$ and ADG $(P=$ $0.012)$, with values significantly higher $(P<0.05)$ than the control by $14.67 \mathrm{~kg}$ and $0.10 \mathrm{~kg} / \mathrm{d}$, respectively. However, differences in these growth performance parameters between $\mathrm{T} 1$ and $\mathrm{T} 2$ and between $\mathrm{T} 2$ and the control were found to be comparable. Moreover, the blood profile of animals after the feeding trial revealed that no ethanol was present in the blood of any animals used in the experiment, while values for albumin, SGPT, SGOT, glucose, total cholesterol, triglycerides and LDL were comparable between all groups. Highest HDL and total blood protein concentration were detected in T2 $(108.44 \mathrm{~g} / \mathrm{dl}$ and $6.61 \mathrm{~g} / \mathrm{dl})$ followed by the control $(99.33 \mathrm{~g} / \mathrm{dl}$ and $6.39 \mathrm{~g} / \mathrm{dl})$ and $\mathrm{T} 1$ $(96.56 \mathrm{~g} / \mathrm{dl}$ and $6.19 \mathrm{~g} / \mathrm{dl})$. Relative to the control, BUN levels were significantly higher in T1 (by $2.32 \mathrm{mg} / \mathrm{dl}$ ) and significantly lower in $\mathrm{T} 2$ (by $3.10 \mathrm{mg} / \mathrm{dl}$ ). Furthermore, the creatinine value for $\mathrm{T} 2$ was $0.17 \mathrm{mg} / \mathrm{dl}$ lower than the comparable values for the control and T1.

\section{Discussion}

In vitro rumen fermentation characteristics

The results of in vitro ruminal fermentation revealed that the replacement of RWR to TMR did not cause a significant change in total gas production as well as $\mathrm{pH}$ level. However, total gas production increased while $\mathrm{pH}$ level decreased with advancing rumen fermentation period of the substrate. Higher gas production could be due to high contents of easily fermentable starches, sugars or hemicelluloses as substrate to rumen microbes [10]. Mamuad et al. [11] added that NFE, total digestible nutrient (TDN), and ruminal fermentation have a directly proportional relationship. High NFE contents of RWR (Table 1) replaced in TMR corroborate high ruminal fermentation which increases total gas production as incubation time became longer and resulted in reduced $\mathrm{pH}$.

High $\mathrm{NH}_{3}-\mathrm{N}$ levels indicate that the soluble fraction of protein is also high, indicating greater catabolism of protein and non-protein nitrogen (NPN) [12]. The ideal concentration of rumen $\mathrm{NH}_{3}-\mathrm{N}$ for an efficient digestion has been estimated to be $3.56 \mathrm{mM}$ to $4.99 \mathrm{mM}$ [13]. Perdock [14] reported that the optimal rumen $\mathrm{NH}_{3}-\mathrm{N}$ concentrations was about $14.27 \mathrm{mM}$. The values obtained for the RWR treatments were higher than those reported 
by Satter and Slyter [13], but lower than those reported by Perdock [14].

Volatile fatty acid, which is the first source of energy for ruminant animals, is influenced by the feed quality, quantity, and allowance method. McDonald et al. [15] reported that the total concentration of VFAs varies widely according to diet and time elapsed since the previous meal, although it is normally in the range of $70 \mathrm{mM}$ to $150 \mathrm{mM}$. In this study, VFA increased gradually with increased incubation periods, and the total concentrations of VFAs were comparable among control and treatment groups after $48 \mathrm{~h}$ of incubation. Feeds high in rapidly fermentable carbohydrates lead to populations of bacteria which produce relatively more propionate and butyrate than acetate [16], that indicate significantly higher butyrate concentration in T2. This indicates that replacement of RWR increased the butyrate concentration, which possessed important function in the intestinal epithelium. Van Nevel and Demeyer [17] stated that when soluble carbohydrates and starchrich diets are fed to ruminants, the production of propionate increases. However, lower NFE in treatment groups were observed and hence, explained the lower propionate concentration after $24 \mathrm{~h}$ of incubation. Nevertheless, comparable propionate concentrations were observed among control and treatment groups were observed after $48 \mathrm{~h}$ of incubation.

Upon evaluation of the VFA concentrations, the ratio of acetic:propionic acid (A:P ratio) reflects rumen fermentation. When rumen fermentation conditions are optimal, the A:P ratio should be greater than 2.2 [15], which corroborates this study. Lower propionate and acetate concentrations in $\mathrm{T} 2$ after $24 \mathrm{~h}$ of incubation can be associated with the diet given. A higher level of fermentable carbohydrate in the diet could lead to a higher level of propionic acid, and thus reduced fiber digestion and possibly acidosis. High levels of acetic acid can indicate a high fiber, low fermentable carbohydrate diet [15]. In the present study, the A:P ratio ranged from 2.03 to 2.15 , but was not significantly different after $48 \mathrm{~h}$ of incubation.

\section{Growth performance and blood profile characteristics Growth performance}

Hanwoo steers fed with $10 \%$ RWR had higher total weight gain, ADG and FE, which means replacement of RWR increased its growth performance. This result was in concordance with Lin et al. [18] data observed when they fed the steers with alcohol-fermented feed diet at growing stage. The steers grew significantly $(P<0.05)$ faster than those fed the control diet. The significant increase $(P<0.01)$ in daily gain in the treatment groups was due to the presence of wet distillers grains (WDG) in the diet, which was comparably with the results reported by Firkins et al. [19]. In addition, other by product used as feed alternative such as brewer's grains has also been reported to produce favorable performance in dairy cows [20] growing calves [21]. National Research Council [22] stated that the CP content of RWR was very similar to that of brewer's dried grains with $28.67 \%$ vs $29.10 \%$. Therefore, improved performances in Hanwoo steers were observed when RWR was used as feed alternative.

\section{Blood metabolites}

As mentioned above, RWR is a by-product of Korean rice wine, and the lack of ethanol in the blood profiles is a good indication that the alcohol content from the residue did not affect the growing Hanwoo steers. Blood albumin concentration was previously reported to decrease with increasing synthesis of muscle proteins [23]; however, no such correlation was observed in the present study. Korean rice wine residue treatment groups achieved a better performance than the control group, consistent with the above statements. A lower SGOT and SGPT were obtained in RWR supplemented growing cattle, and Kim et al. [24] found that the low levels of SGOT and SGPT were favorable for healthy cattle. Serum proteins are believed to be indicative of the nutritional status of the animal, and constitute a portion of the amino acid pool of the body [25]. Biochemically, the higher blood total protein and albumin concentration in both treatments were in the normal range [26]. BUN in cattle was affected by dietary levels of protein and energy [27], hence lower BUN was observed in T2. Also, the lower correlation between serum BUN and protein in steers fed fermented feed could result from the increase in BUN levels and the reduction in protein synthesis, and vice versa [28]. The rumen microflora metabolizes a larger percentage of urea than the enteric flora in monogastric animals, often preventing BUN concentrations being increasing proportionately with creatinine levels in cattle [29].

In the present study, the creatinine concentration in calves fed the basal diet alone was below the normal range. Lin et al. [18] reported that providing alcoholfermented feed to ruminants increased the propionate, triglyceride, cholesterol and glucose concentrations in the blood with increasing weight gain. The findings of this experiment did not differ with regard to LDL concentrations among the control and treatment groups. However, the HDL concentrations of T2 differed significantly among the control and treatment groups. Body fat is correlated with HDL and LDL concentrations, with increases in body weight or fat resulting in increased HDL and LDL levels [24]. The results of the present study revealed similar LDL levels in the control and treatment, which were favorable for animals and similar to the views described above. 


\section{Conclusion}

These results suggest that TMR amended with $15 \%$ RWR can be used as an alternative feed resource for ruminants to reduce feed cost while increasing ADG and total gain.

\section{Competing interests}

The authors declare that they have no conflict of interests in the research.

\section{Authors' contributions}

CJ and LM carried out the in vitro and in vivo experiments, performed the statistical analyses, and drafted the manuscript. YK and HS performed the feed formulation of this experiment. KP and $Y L$ participated in the design of the study and served as consultant. SL proposed and made this project as well as managed the entire experiment. All authors have contributed significantly, and in agreement with the content of the manuscript. All authors read and approved the final manuscript.

\section{Acknowledgment}

This research was supported by Korea Institute of Planning and Evaluation for Technology in Food, Agriculture, Forestry and Fisheries (Project No. 314075-03-1-HD040)

\section{Author details}

${ }^{1}$ Ruminant Nutrition and Anaerobe Laboratory, Department of Animal Science and Technology, College of Bio-industry Science, Sunchon Nationa University, 413 Jungang-ro, Suncheon, Jeonnam 57922, Republic of Korea. ${ }^{2}$ National Agricultural Cooperative Federation, Anseong-si, Gyeonggi-do 456-824, South Korea. ${ }^{3}$ Adbiotech Co. Ltd., Chun-Cheon City 200-880, Republic of Korea. ${ }^{4}$ Animal Resources Research Center, School of Animal Life and Science, Konkuk University, 120 Neungdong-ro, Gwangjin-gu, Seoul 05029, South Korea. ${ }^{5}$ Rural Development Administration, National Institute of Animal Science, Wanjugun, Jeollabukdo, South Korea.

Received: 27 October 2015 Accepted: 30 December 2016

Published online: 11 January 2016

References

1. Xu C, Cai Y, Moriya N, Ogawa M. Nutritive value for ruminants of green tea grounds as a replacement of brewers' grains in totally mixed ration silage. Anim Feed Sci Tech. 2007;138:228-38.

2. Larson EM, Stock RA, Klopfenstein TJ, Sindt MH, Shain DH. Energy value of hominy feed for finishing ruminants. J Anim Sci. 1993;71:1092-9.

3. Kim IY, Ahn GC, Kwak HJ, Lee YK, Oh YK, Lee SS, et al. Characteristics of wet and dried distillers grains on in vitro ruminal fermentation and effects of dietary wet distillers grains on performance of Hanwoo steers. Asian Australas J Anim Sci. 2015:28:632-8.

4. Piao MY, Kim HJ, Seo JK, Park TS, Yoon JS, Kim KH, et al. Effects of synchronization of carbohydrate and protein supply in total mixed ration with Korean rice wine residue on ruminal fermentation, nitrogen metabolism and microbial protein synthesis in Holstein steers. Asian Australas J Anim Sci. 2012;25:1568-74

5. AOAC. Official methods of analysis of the Association of Official Analytical Chemists. Gaithersburg: AOAC International; 2005.

6. Russell JB, Van Soest PJ. In vitro ruminal fermentation of organic acids common in forage. Appl Environ Microbiol. 1984;47:155-9.

7. Chaney AL, Marbach EP. Modified reagents for determination of urea and ammonia. Clin Chem. 1962:8:130-2.

8. Tabaru H, Kadota E, Yamada H, Sasaki N, Takeuchi A. Determination of volatile fatty acids and lactic acid in bovine plasma and ruminal fluid by high performance liquid chromatography. Jpn J Vet Sci. 1988;50:1124-6.

9. SAS. SAS/STAT. Statistical analysis systems for windows. Release 9.1. Cary: SAS Institute Inc; 2004. p. 423.

10. Jeong C-D, Mamuad LL, Kim S-H, Choi YJ, Soriano AP, Cho KK, et al. Effect of soybean meal and soluble starch on biogenic amine production and microbial diversity using in vitro rumen fermentation. Asian - Australas J Anim Sci. 2015;28:50.

11. Mamuad L, Kim SH, Jeong CD, Choi YJ, Jeon CO, Lee S-S. Effect of fumarate reducing bacteria on in vitro rumen fermentation, methane mitigation and microbial diversity. J Microbiol. 2014;52:120-8.
12. Soriano AP, Mamuad LL, Kim S-H, Choi YJ, Jeong CD, Bae GS, et al. Effect of Lactobacillus mucosae on in vitro rumen fermentation characteristics of dried brewers grain, methane production and bacterial diversity. Asian Australas J Anim Sci. 2014;27:1562-70

13. Satter LD, Slyter LL. Effect of ammonia concentration of rumen microbial protein production in vitro. Br J Nutr. 1974;32:199-208.

14. Perdock HB. Ammoniated rice straw as a feed for growing cattle. University of New England. 1988.

15. McDonald P, Edwards RA, Greenhalgh JFD, Morgan CA. Animal nutrition. Harlow: Longman; 1995

16. Moran J. Tropical dairy farming: Feeding management for small holder dairy farmers in the humid tropics. Kyabram Dairy Research Centre DPI (Victoria). Landlinks Press. 2005.

17. Van Nevel CJ, Demeyer DI. Effect of monensin on rumen metabolism in vitro. Appl Environ Microbiol. 1977:34:251-7.

18. Lin GZ, Kim BW, Kim HS, Sung Kl, Ohh SJ, Hong BJ, et al. Changes in serum metabolites and growth characteristics of Korean native steers fed alcoholfermented feeds. Asian-Australas J Anim Sci. 2004;17:648-54.

19. Firkins $\mathrm{L}$, Berger LL, Fahey GCJ. Evaluation of wet and dry corn gluten feeds for ruminants. J Anim Sci Technol (Kor). 1985:60:847-60.

20. Polan CE, Herrington TA, Wark WA, Armentano LE. Milk production response to diets supplemented with dried brewers grains, wet brewers grains, or soybean meal. J Dairy Sci. 1985;68:2016-26.

21. Rounds W, Klopfenstein T. Brewers dried grains in ruminant rations. J Anim Sci. 1975;41:415-6.

22. NRC. Nutrient requirements of dairy cattle. Washington, D.C.: National Academy Press; 2001.

23. Galbraith H, Dempster DG, Miller TB. A note on the effect of castration on the growth performance and concentrations of some blood metabolites and hormones in British Fresian male cattle. Anim Prod. 1978;26:339-42.

24. Kim SH, Alam MJ, Gu MJ, Park KW, Jeon CO, Ha JK, et al. Effect of total mixed ration with fermented feed on ruminal in vitro fermentation, growth performance and blood characteristics of Hanwoo steers. Asian - Australas J Anim Sci. 2012;25:213-23.

25. Kim JH, Mamuad LL, Yang CJ, Kim SH, Ha JK, Lee WS, et al. Hemato-biochemica and cortisol profile of Holstein growing-calves supplemented with vitamin C during summer season. Asian-Australas J Anim Sci. 2012;25:361-8.

26. Seifi HA, Mohri M, Delaramy M, Harati M. Effect of short term oversupplementation of ascorbic acid on hematology, serum biochemistry, and growth performance of neonatal dairy calves. Food Chem Toxicol. 2010;48:2059-62

27. Addis T, Barrett E, Poo LJ, Yuen DW. The relationship between the serum urea concentration and the protein consumption of normal individuals. I Clin Invest. 1947:26:869-74.

28. Lieber CS. Microsomal ethanol-oxidizing system (MEOS): the first 30 years (1968-1998)-a review. Alcohol Clin Exp Res. 1999:23:991-1007.

29. Miller SC, LeRoy BE, Tarpley HL, Bain PJ, and Latimer KS. posting date. A Brief Review of Creatinine Concentration. Veterinary Clinical Pathology Clerkship Program. 2004. [Online.]

\section{Submit your next manuscript to BioMed Central} and we will help you at every step:

- We accept pre-submission inquiries

- Our selector tool helps you to find the most relevant journal

- We provide round the clock customer support

- Convenient online submission

- Thorough peer review

- Inclusion in PubMed and all major indexing services

- Maximum visibility for your research

Submit your manuscript at www.biomedcentral.com/submit
Biomed Central 